\title{
The Genealogy of Culturalist International Relations in Japan and Its Implications for Post-Western Discourse
}

\author{
Kosuke Shimizu \\ Ryukoku University
}

\begin{abstract}
This paper aims to introduce a neglected methodology from Japanese international relations (IR) - the culturalist methodology - to Anglophone specialists in IR. This methodology is neglected not only by an Anglophone audience but also by Japanese IR scholars. I argue here that despite this negligence, the culturalist methodology has great potential to contribute to contemporary post-Western international relations theory (IRT) literature by posing radical questions about the ontology of $I R$, as it questions not only the ontology of Western IR, but also the IR discourses developed in the rest of the world. Consequently, in understanding and imagining the contemporary world, I clarify the importance of perceptions based on what, in Japan, are commonly called 'international cultural relations' (kokusai bunka) and 'regional history' (chiikishi). I also indicate how our perceptions of the world are limited by the Westphalian principles of state sovereignty and non-intervention among 'equal' nations on the basis of state borders. While historical understanding is widely recognised as an important approach to contemporary $I R$, its scope is limited by its universalised principles.
\end{abstract}

Keywords: Japanese IR, diplomatic history, international cultural relations, regional history, post-Western IR theories

\section{Introduction}

This paper aims to introduce a neglected methodology from Japanese international relations (IR), namely, the culturalist methodology, to Anglophone specialists in IR. Interestingly, this methodology is neglected not only by an Anglophone audience but also by Japanese IR scholars. I argue here that despite this negligence, the culturalist methodology has great potential to contribute to contemporary post-Western international relations theory (IRT) literature by posing radical questions about the ontology of IR.

Post-Western IRT differs from non-Western IRT in that the latter complements the established mainstream IR literature largely developed in the Anglophone world, and the former radically criticises conventional approaches by questioning their ontological assumptions. ${ }^{1}$ In this sense, the culturalist methodology I introduce is very much post-Western; it questions not only the ontology of Western IR, but also that of the IR discourses developed in the rest of the world. It is worth noting, however, that post-Western IR discourses are not given serious consideration even in the rest of the world. ${ }^{2}$

Kosuke Shimizu, Department of Global Studies, Ryukoku University. Email: shimizu@world.ryukoku.ac.jp.

Kosuke Shimizu, "Materializing the 'Non-Western': Two Stories of Japanese Philosophers on Culture and Politics in the Inter-war Period," Cambridge Review of International Affairs 28, no. 1 (2015): 3-20; Giorgio Shani, "Towards a post-Western IR: The Umma, Khalsa Panth, and critical international relations theory," International Studies Review 10, no.4 (2008): $722-34$.

2 Amitav Acharya, "International Relations Theory and the 'Rise of Asia'," in Oxford Handbook of the International Relations 
In this article, I clarify the importance of perceptions on the basis of what, in Japan, are commonly called 'international cultural relations' [kokusai bunka] and 'regional history' [chiikishi] in understanding and imagining the contemporary world. I also indicate how our perceptions of the world are limited by the Westphalian principles of state sovereignty and non-intervention among 'equal' nations on the basis of state borders. While historical understanding is widely recognised as an important approach to contemporary IR, its scope is also limited by its universalised principles, and as a result, only diplomatic history has been regarded as a part of IR. Despite the introduction of culture into the IR literature by diplomatic history through the works of Akira Irie, international cultural relations by Kenichiro Hirano and regional history by Takeshi Hamashita (works introduced shortly), the importance of cultural exchange has never attracted sufficient attention from an IR audience. As a result, when we think of an alternative to the contemporary international order, it is recounted using the Westphalian mind-set, in terms of such expressions as China's tribute system, guanxi or tianxia, in which 'China' directly connotes the People's Republic of China, rather than seeing the method as a governing system of the world. ${ }^{3}$ Similarly, state-makers use 'Japan' to confirm a political body on the basis of state sovereignty.

Such is the case in Japan's diplomacy, particularly when it comes to the issue of soft power politics. Japan is now trying to become more politically and economically influential over other Asian countries by using its culture, such as animation films and pop culture. Ironically, however, the cultural products of Japan that diplomats strive to promote sometimes appear to be based on a concept of pre-state sovereignty rather than the culture of Japan as a nationstate. $^{4}$

There seems to be a substantial number of similar ontological deficiencies in the discourses of contemporary IR in general, and even more so when they deal with the idea of culture and cultural politics. In developing my argument on culturalist politics, I clarify why mainstream IR scholars do not give serious consideration to post-Western IRT by focusing upon Japanese IR, as an example that has disregarded culturalist methodology, and to draw lessons for the further development of post-Western IRT discourse. This paper focuses on the following questions: 1.) What is the culturalist methodology? 2.) Why have mainstream Japanese IR scholars regarded this methodology as unimportant? 3.) To what extent does the genealogical investigation of the culturalist methodology contribute to the existing postWestern IRT literature and how?

To address these questions, I start with the second one. I then focus on a particular approach to diplomatic history, developed by Akira Irie, which attempts to historicise Japanese foreign policy by concentrating on cultural relations among nations. This is the first example of a historical approach to world affairs with a specific focus on the relationship between diplomacy and culture. After this, I examine the international cultural relations approach developed by Kenichiro Hirano, which is an even more radical departure from the traditional diplomatic history tradition. This approach differs from Irie's radical approach to diplomatic

of Asia, eds. Saadia Pekkanen, et.al. (New York: Oxford University Press, 2015), 126.

3 Yaqing Qin, "A Relational Theory of World Politics," International Studies Review 18, no. 1 (2016): 33-47; Yaqing Qin, "Rule, Rules, and Relations: Towards a Synthetic Approach to Governance," The Chinese Journal of International Politics 4, no. 2 (2011): 117-45; Tingyang Zhao, "Rethinking Empire from a Chinese Concept 'All-under-Heaven'," Social Identities 12, no. 1 (2006): 29-41.

4 Kosuke Shimizu, “The ambivalent relationship of Japan's soft power diplomacy and Princess Mononoke: Tosaka Jun's philosophy of culture as moral reflection," Japanese Journal of Political Science 15, no. 4 (2014): 683-98. 
history in the sense that it takes into account intercultural relations as a whole and acts as a bridge between diplomatic history and the study of regional history, which I introduce in the following chapter. I then introduce an approach to East Asian history mainly developed by Takeshi Hamashita, which I assess in terms of the contribution it can make to contemporary IR literature. Following the explanation of Hamashita's approach to regional history, I extract some conclusions to contribute to the progress of post-Western IRT literature.

\section{Genealogy of Japanese IR and the Reason for its Neglect}

There have been comprehensive surveys of Japanese IR, most prominently by Takashi Inoguchi, who has been engaged in an extensive attempt to introduce and analyse the genealogy of Japanese IR for more than ten years. ${ }^{5}$ Of the introductory texts to Japanese IR, his works are particularly detailed, informative and comprehensive. In his articles, Inoguchi argues that Japanese IR consists of at least four distinctive traditions: the Staatslehre tradition, Marxism, Historicism and American-style methodology. The Staatslehre tradition refers to policy studies for the state. It is mainly composed of state policy and external strategy. Marxism was very strong until the 1960s and was associated with the conception of Oppositionswissenschaft, which literally means 'opposition science'. Historicism, a historycentred approach to international relations, is still strong, and many IR researchers in Japan adopt it. American-style methodology appeared after World War II under the strong political influence of the United States. European influence over Japanese intellectuals had been evident before the war, and Inoguchi contends that the American approach took over in the post-war era. ${ }^{6}$

Inoguchi's introduction of Japanese IR to an Anglophone audience is comprehensive and detailed, but he does not explain historicism in detail, particularly when it comes to the collaborative works of historical IR with area studies of Asia; that is, the study of regional history. As he explains the historical approach to IR only in terms of diplomatic history or historical studies, in collaboration with the Staatslehre tradition, his focus is rarely directed to research based on the perception from the margins, which is the methodology that many scholars of regional history use. The neglect of this methodology is not confined to Inoguchi's explanation, however. When an introduction to Japanese IR is presented and the study of history is touched upon, it is not unusual for this 'history' to mean diplomatic history, not regional history, and this propensity is even more evident in the introductory texts to Japanese IR published recently. ${ }^{7}$ Like Inoguchi, they mention the historical approaches to Japanese IR in general, but their explanations focus solely on Japan's diplomatic history or the history of Japan as a nation-state, and stop at an introductory level when it comes to regional history or regional studies. Consequently, they do not present an adequate research results or published works related to diverse culture or history.

Recent years have also seen numerous books and articles published on Japanese IR in English. Glen Hook published two volumes in 2001, titled Japan's International Relations:

5 Takashi Inoguchi, "Are There Any Theories of International Relations in Japan?" International Relations of the AsiaPacific 7, no. 3 (2007): 369-90; Takashi Inoguchi and Paul Bacon, "The Study of International Relations in Japan: Towards a More International Discipline," International Relations of the Asia-Pacific 1, no. 1 (2001): 1-20.

6 Inoguchi and Bacon, "The Study of International Relations," 11-2; Inoguchi, "Are There Any Theories," 371-3.

7 Koji Murata, "The Evolution of Japanese Studies of International Relations," Japanese Journal of Political Science 11, no. 3 (2010): 355-65; Kazuya Yamamoto, "International Relations Studies and Theories in Japan: A Trajectory Shaped by War, Pacifism, and Globalization," International Relations of the Asia-Pacific 11, no. 2 (2011): 259-78. 
Politics, Economics and Security and Japan and Okinawa: Structure and Subjectivity. ${ }^{8}$ The focus of Shogo Suzuki's recent critique of the English School, Civilization and Empire: China and Japan's Encounter with European International Society, also covers Japan and China. ${ }^{9}$ Chris Goto-Jones published a single authored monograph, and an edited volume, Re-Politicising the Kyoto School as Philosophy. ${ }^{10}$ If we include the historical understanding of Japan's diplomacy, Alan Tansman's The Culture of Japanese Fascism, ${ }^{11}$ Eri Hotta's Japan 1941: Countdown to Infamy and Pan-Asianism and Japan's War: 1931-1945, and Louise Young's Japan's Total Empire: Manchuria and the Culture of Wartime Imperialism constitute good examples. ${ }^{12}$

Works published in book form abroad deal mainly with Japanese foreign relations and diplomatic history, and not many examine intellectual history or theories of Japanese IR as an academic discipline. With regard to the intellectual history of IR in Japan, we seem to see more in the way of journal articles than books. In fact, since the publication of Inoguchi's work on the four traditions, ${ }^{13}$ there have been several successive articles about the field. Some of them present an overview of Japanese IR, ${ }^{14}$ some engage in critical reflection ${ }^{15}$ and some focus on particular Japanese intellectuals. ${ }^{16}$

However, as mentioned earlier, such works are characterised by a lack of attention when it comes to the study of a regional history of Asia. Kazuya Yamamoto has come close to recognising this lack, noting that 'Japan's IR studies have been characterised by their historical approaches'. As Inoguchi has suggested, Yamamoto maintains that this is why Japanese IR has been characterised by a lack of interest in theoretical development. ${ }^{17}$ Inoguchi and Yamamoto have introduced a historical methodology called historicism, which is, in their perception, characterised by its concreteness and this concreteness only emphasises the lack of development of abstract theories in Japan. When Inoguchi and Yamamoto refer to IR theory, it is a theory that must be abstract and constructed on the basis of universality, objectivity, regularity, predictability and falsifiability. In other words, it must be scientific. This was particularly salient in the case of American IR, ${ }^{18}$ which has had an undeniable

\footnotetext{
${ }^{8}$ Glenn D. Hook, Julie Gilson, Christopher W. Hughes, and Hugo Dobson, Japan's International Relations: Politics, Economics and Security (London: Routledge, 2001); Glenn D. Hook and Richard Siddle, eds., Japan and Okinawa: Structure and Subjectivity (London: Routledge Curzon, 2001).

9 Shogo Suzuki, Civilization and Empire: China and Japan's Encounter with European International Society (London: Routledge, 2009).

${ }_{10}$ Chris Goto-Jones, Political Philosophy in Japan: Nishida, the Kyoto School, and Co-Prosperity (London: Routledge, 2005); Chris Goto-Jones, ed., Re-Politicising the Kyoto School as Philosophy (London: Routledge, 2008).

11 Alan Tansman, ed., The Culture of Japanese Fascism (Durham, N.C.: Duke University Press, 2009).

${ }_{12}$ Eri Hotta, Japan 1941: Countdown to Infamy, (New York: Alfred A. Knopf, 2013); Eri Hotta, Pan-Asianism and Japan's War: 1931-1945 (Basingstoke: Palgrave/Macmillan, 2007); Louise Young, Japan's Total Empire: Manchuria and the Culture of Wartime Imperialism (Berkeley: University of California Press, 1998).

${ }_{13}^{13}$ Inoguchi, "Are There Any Theories"; Inoguchi and Bacon, "The Study of International Relations".

${ }_{14}$ Murata, "The Evolution of Japanese Studies"; Yamamoto, "“International Relations Studies".

${ }_{15}$ Ching-Chang Chen, "The Absence of Non-Western IR Theory in Asia Reconsidered," International Relations of the AsiaPacific 11, no. 1 (2011): 1-23; Ching-Chang Chen, "The Im/Possibility of Building Indigenous Theories in a Hegemonic Discipline: The Case of Japanese International Relations," Asian Perspective 36, no. 3 (2012): 463-92.

${ }^{16}$ Ryoko Nakano, "Pre-History' of International Relations in Japan: Yanaihara Tadao's Dual Perspective of Empire," Millennium 35, no. 2 (2007): 301-9; Kosuke Shimizu, "Nishida Kitaro and Japan's Interwar Foreign Policy: War Involvement and Culturalist Political Discourse," International Relations of the Asia-Pacific 11, no. 1 (2011): 157-83; Kosuke Shimizu, "Materializing the 'Non-Western': Two Stories of Japanese Philosophers on Culture and Politics in the Inter-war Period," Cambridge Review of International Affairs 28, no. 1 (2015): 3-20; Kuan-Hsing Chen, 'Takeuchi Yoshimi's 1960 'Asia as Method” Lecture'," Inter-Asia Cultural Studies 13, no. 2 (2012): 317-24; Seok-Won Lee, "Empire and Social Science: Shinmei Masamichi and the East Asian Community in Interwar Japan," Social Science Japan Journal 17, no. 1 (2013): 59-76.

17 Kazuya Yamamoto, "International Relations Studies and Theories in Japan: A Trajectory Shaped by War, Pacifism, and Globalization," International Relations of the Asia-Pacific 11, no. 2 (2011): 260.

${ }_{18}$ Steve Smith, Ken Booth, and Marysia Zalewski, International Theory: Positivism and Beyond (Cambridge: Cambridge University Press,1998).
} 
influence on Japanese IR. As a result, the importance of any new methodologies developed in Japan appears to be worth mentioning only when it has an appropriate counterpart in Western IR literature, and American literature in particular. In other words, Western IR was, and still is, the unchangeable reference point for Japanese IR. Obviously, this definition of 'theory' is very much narrowly defined. Jun Tosaka, a Kyoto School philosopher of the inter-war period, argues that theories critical of the prevailing order only emanate from concrete experiences of everyday lives. ${ }^{19}$ For Tosaka, a theory is not just to explain what it is; it must also involve what it should be. In other words, the definition of 'theory' Inoguchi and Yamamoto have in mind is one possible definition of theory, and certainly does not include the critical theories in the Coxian sense. ${ }^{20}$ In this way, the academic atmosphere indeed continuously ushers Japanese IR scholars towards a definition of 'theory' to be universalised and abstract.

The historicism that Inoguchi and Yamamoto mention requires further explanation. In an article on Japanese IR published in 2007, Inoguchi discussed two different traditions within historical studies: Staatslehre and historicism. Here 'historicism' means the study of regional history. The Staatslehre tradition 'greatly influenced military and colonial studies in the pre-war period and remained strong in a metamorphosed form even after 1945, ${ }^{21}$ This tradition's priority was to provide sufficient historical-institutional background and to describe events and personalities in context and their consequences in detail. Research recently conducted in this tradition has been in the form of regional studies, not regional history, on the basis of the sovereign state (e.g. Chinese studies, Thai studies, Indonesian studies, etc.) and has maintained a close relationship with the government. In fact, the bulk of research in this tradition has been conducted by government-related think tanks. ${ }^{22}$ From a Foucauldian perspective, power/knowledge relations appear very much intact because of their close relationship with the government.

One of the reasons for this intimate relationship between government and regional studies is related to the origins of IR. According to Tadashi Kawata and Saburo Ninomiya, prior to World War I, world affairs were not as important as domestic affairs as a subject of scholarly interest; rather, they were dealt with in the field of international law or diplomatic history. ${ }^{23}$ This thinking parallels E. H. Carr's argument in The Twenty Years' Crisis: 19191939 and Stanley Hoffmann's article 'An American Social Science: International Relations', published in 1977, which maintain that international relations was exclusively the business of diplomats and international lawyers before World War I. ${ }^{24}$ Post-war Japanese IR inherited this perception and, as a consequence, Staatslehre became the mainstream discourse of Japanese foreign relations.

Inoguchi explains in this context that 'the strong salience of area studies in Japan's IR study ... reflects in part the reaction of academics to the domination of the Staatslehre tradition ${ }^{25}$ and many scholars in this tradition have adopted the regional-history methodology of historicism. In an historical survey of Japanese post-war IRTs, Yamamoto also touches

\footnotetext{
19 Shimizu, "Materializing the 'Non-Western",

20 Robert Cox, "Social Forces, States and World Orders: Beyond international relations theory," Millennium 10, no. 2 (1981): $126-55$

21 Inoguchi, "Are There Any Theories," 372.

22 Inoguchi, "Are There Any Theories," 372.

23 Tadashi Kawata and Saburo Ninomiya, "The Development of the Study of International Relations in Japan," The Developing Economies 2, no. 2 (1964): 190.

24 E. H. Carr, The Twenty Years' Crisis: 1919-1939 (London: Macmillan, 1946); Stanley Hoffmann, "An American Social Science: International Relations," Daedalus 106, no. 3 (1977): 41-60.

25 Inoguchi, "Are There Any Theories," 372.
} 
upon the historicism of area studies in explaining the diversification of Japanese IR theory. He explains that Japanese IR diversified after the end of the Cold War and that area studies constituted an aspect of this. He sees the branch of area studies, or regional history, within IR as under the profound influence of Immanuel Wallerstein's World Systems Theory and contends that

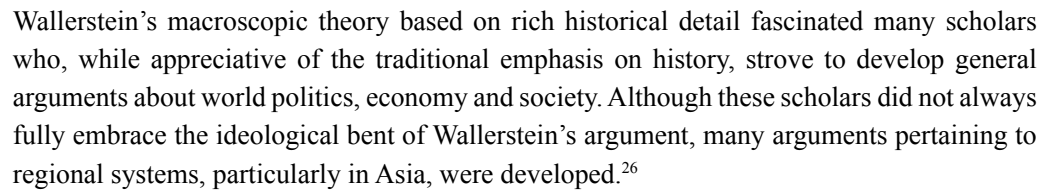

This description of historical methodology presumably refers to the study of regional history, which I introduce shortly.

Another explanation of the lack of culturalist tradition in Japan is provided by Sakai Tetsuya, a prominent diplomatic historian of contemporary Japanese IR. Tetsuya Sakai tries to situate the narratives of culturalists and regional history scholars on the margins of IR by focusing on the humanities, arguing that the reason why the voices of the scholars of regional history have been disregarded is because of IR's two different but intertwined world orders. ${ }^{27}$ Examining a number of intellectuals from the past who could be regarded as having been situated at the margins of conventional IR literature, he notes that many of them concentrated on non-state actors and their interactions across state boundaries.

According to Sakai, the study of regional history in Japanese IR has a long history. Initially, the study of Japan's foreign relations was divided into, on the one hand, international law and politics, and on the other, colonial policy studies. Sakai contends that the former was naturally associated closely with law, politics and economics and the latter with the humanities, including literature, ethnology and history. Sakai argues that IR literature used to be developed on the basis of the division between international relations and colonial policy studies, as the disciplines researching the 'international order' and the 'imperial order', respectively.

The term 'international order' refers here to the relationship between equal states, mostly in the European context, while 'imperial order' was an order mainly forcibly placed on the areas outside of that context. The former was, and still is, more about the institutional arrangements and organisational management of politics and international law effective among relatively equal members - mainly European nation-states - and the latter was more about blunt and bare economic and cultural power over those who were colonised. ${ }^{28}$

These two orders of the world profoundly influenced the development of intellectual society in Japan, with the former becoming the core of the discipline of IR and the latter that of regional and colonial studies, even though the two orders are inseparable in a sense that the international order was maintained practically by the suzerain states' unceasing exploitation of the colonised areas, and thus by the imperial order.

The two-order understanding of world affairs is by no means limited to Japan, of course. Similar arguments can be found in Edward Keene's account of the Westphalian system and colonial system and Shogo Suzuki's criticism of British IR, in which they contend that IR only

26 Yamamoto, "International Relations Studies".

27 Tetsuya Sakai, Kindai Nihon no Kokusai Chitsujo [International order of modern Japan] (Tokyo: Iwanami, 2007).

28 Sakai, Kindai Nihon, 6-7. 
concentrates on international society and does not pay sufficient attention to the functioning of imperialism in supporting the former. ${ }^{29}$ Japanese IR has mainly developed along with the international order in this sense, and has rarely given academic attention to the imperial order simply because the latter was regarded as the subject of regional and colonial studies. By contrast, some scholars of regional studies were well aware, thanks to their empirical and ethnological research in colonised areas, of how important violent control over those areas was in maintaining the international order and of its devastating effect on the colonised. This is precisely what Hirano's theory of international cultural relations and Hamashita's discourse of regional history tried to point out when they emphasised the importance of looking at the world from the margins on the basis of cultural relations. Those who critically engaged in regional and colonial studies, particularly in the post-World War II era, were thus inclined to formulate counter-discourses to that of mainstream IR, but they were gradually pushed out by those residing in mainstream IR in Japan and into the discipline of regional studies, that is, regional studies scholars for state-centrism, who developed their studies to maintain the status quo of international order and so remain in the IR scholarly circle.

Sakai argues that the above is one of the most important reasons for the lack of attention by Japanese IR to the studies of cultural politics or regional history. However, as we have seen, individual cultural theorists of IR are all too well aware of the power of the term 'culture', and in the cases of Hirano and Hamashita in particular, strive to relativise and provide counterarguments to the essentialised reading of culture mainly formulated in the West, such as Huntington's 'clash of civilisations' thesis.

\section{Diplomatic History and Culture}

As an aspect of historical studies, the study of regional history within Japanese IR mainly developed alongside regional studies of Asia; it is often referred to as chiikishi or 'regional history', and focuses mostly on economic and cultural exchanges among Asian nations and their effects on diplomatic and political relations. Naturally, it contrasts sharply with the historical approach to diplomatic relations, which either separates diplomatic history from economy and culture or presumes the determinism of foreign relations over economy and culture. While diplomatic history has been generally regarded as a part of IR, the study of regional history has never been as legitimate an approach to contemporary IR as the history of diplomacy has.

One of the salient characteristics of the study of regional history is its specific focus on culture. It strives to theorise world affairs in a more comprehensive manner than the traditional mainstream IR literature does. However, the introduction of culture into IR literature was done by diplomatic history. It came to be more explicit indeed when radical diplomatic historians took it up as their methodology. The most widely known of Japanese scholars to Western readers in this context is Akira Iriye, an emeritus professor of history at Harvard University, also known for his extensive writing on Japan's external relations, particularly on 'cultural internationalism'. He personally experienced the defeat of World War II and the chaotic social conditions of the post-war period, which likely influenced his subsequent research.

${ }^{29}$ Edward Keene, Beyond Anarchical Society: Grotius, Colonialism and Order in World Politics (Cambridge: Cambridge University Press, 2002); Suzuki, Civilization and Empire, 11. 
Generally speaking, the study of diplomatic history consists of research into the history of the foreign relations of one or a few countries, and the main target is either nation-states or diplomats. While Iriye is a historian of Japanese diplomatic history in the ordinary sense, unconventionally he focuses on the cultural aspects of diplomacy. To explain the aim of his research, he says that

\begin{abstract}
Japanese foreign relations are not simple. If we are to understand the international order as a whole, we need at least to take into account the three dimensions of military, economy and thought (or culture). Sometimes they are complementary to each other; sometimes they are contradictory. Either way, this [approach] will provide a perspective to understand the ways in which Japan has interacted with the world by focusing upon the changes of Japan's military, economic and cultural relations in the last 50 years. ${ }^{30}$
\end{abstract}

Although Iriye has argued that we need to focus on military, economic and cultural dimensions to understand contemporary international relations, his academic inclination towards the cultural activities of the international arena has been highly salient throughout his writings. This approach was a radical departure from the conventional understanding of diplomatic history and marked the advent of a new, cultural approach to diplomacy, later to be developed fully in Joseph Nye's soft-power politics. Iriye published such culture-oriented monographs as Power and Culture: The Japanese American War 1941-1945 and Cultural Internationalism and World Order, both of which have an exclusive focus on culture and its relationship to diplomacy.

According to Iriye, the focus on culture has great significance for IR literature because it means a move away from the state-centric view of IR towards an academic area that previously was not focused upon. In explaining the purpose of his book Cultural Internationalism and World Order, published in 1997, he writes, 'I hope the book will show that it is perfectly possible to narrate the drama of international relations without giving principal roles to separate national existences'. ${ }^{31}$ Iriye maintains that while the nation-state is undoubtedly a main focus of IR, he also believes that 'interactions outside the (state-centric) framework exist, for which international relations may be an inadequate term but which, whatever one calls them, constitute just as much part of the story of world development as do the activities of national entities'. ${ }^{32}$ This belief in the importance of the activities of non-state actors in shaping world affairs is the theoretical foundation on which his argument concerning cultural politics is based.

Focusing on culture not only contributes to making sense of the shaping process of world affairs but also of the changing process of the world. His book argues that

\footnotetext{
[i]ndividuals and groups of people from different lands have sought to develop an alternative community of nations and peoples on the basis of their cultural interchanges and... while frequently ridiculed by practitioners of power politics and ignored by historians, their efforts have significantly altered the world community and immeasurably enriched our understanding of international affairs. ${ }^{33}$
}

Thus, Iriye argues, the importance of culture is undeniable or indispensable in understanding world affairs, and the importance emanates from the diversity in cultural practices.

${ }^{30}$ Akira Iriye, Shin Nihon no Gaiko: Chikyuka Jidai no Nihon no Sentaku [New diplomacy of Japan: Japan's choice in the global era] (Tokyo: Chuokoron, 1991), 8, original in Japanese, author's translation.

${ }^{31}$ Akira Iriye, Cultural Internationalism and World Order (Baltimore: Johns Hopkins University Press, 1997), 1.

32 Iriye, Cultural Internationalism, 1.

33 Iriye, Cultural Internationalism, 2. 
However, this task is not all that easy because the term 'culture' is highly problematic and has a variety of meanings. There have been numerous definitions and interpretations of the term and there seems to be no universally accepted definition on which every researcher has agreed. Conscious of the need to find his own definition, Iriye defines it as 'structures of meaning'. In this interpretation, the main focus in the cultural dimension to world affairs is on 'a variety of activities undertaken to link countries and peoples through the exchange of ideas and persons, through scholarly cooperation, or through efforts at facilitating crossnational understanding, ${ }^{34}$

This definition, in turn, directs us to a new definition of IR. Iriye writes that

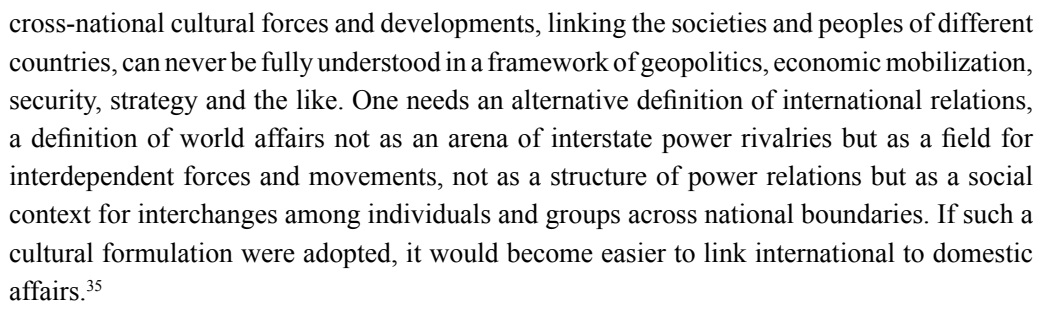

For Iriye, the term 'international relations' does not seem adequate for the discipline. IR is from the outset inter-national. However, as our scholarly targets include non-state actors and exchanges among them, new names for our academic interests are definitely needed.

Iriye sees that this methodology is omitted from general academic interests, mainly because of the peculiar history of Japanese intellectuals. In the period prior to the WWII, some historians and IR scholars, such as the Kyoto School of philosophy, advocated (similar arguments to Iriye's arguments) that cultural exchange would lead to the peaceful reconciliation of contending nation-states. Unfortunately, history tells us the tragic story that their discourses were abused by nationalists to justify the aggressive territorial expansion of Imperialist Japan. ${ }^{36}$ Thus 'culture' is a term which Japanese intellectuals have consciously and carefully avoided. To prevent repetition of this sad history, Iriye predicts that

cultural internationalists in all countries will need to struggle against cultural chauvinists as well as geopolitical nationalists; that is, both against parochial tendencies that deny possibilities for cross-cultural communication and against policy formulations that give primacy to military considerations. ${ }^{37}$

In this way, Iriye criticises the essentialised understanding of culture and maintains his critical stance against mainstream Western IR methodology.

What effects has Iriye's argument had? He definitely expanded the intellectual territory of IR and opened a space for the development of what diplomatic history could have become. However, not many Japanese scholars clearly grasped the meaning of his methodological case to introduce culture into IR. As a result, Japanese IR theorists did not pay sufficient attention to Iriye's cultural methodology as an IR theory. His argument was consigned to the category of a mere variant of Japanese diplomatic history, which has nothing to do with the theorisation of IR. As a result, Iriye is still regarded as a historian, not a theorist, despite his argument's potential to be developed into an alternative theory of IR.

\footnotetext{
${ }^{34}$ Iriye, Cultural Internationalism, 3.

35 Iriye, Cultural Internationalism, 180-1.

${ }^{36}$ Kosuke Shimizu, "Nishida Kitaro," 157-83; Shimizu, "Materializing the 'Non-Western"”.

37 Irie, Cultural Internationalism.
} 


\section{International Cultural Relations}

While Iriye's attempt to widen the scope of IR was definitely a step towards a more cultureoriented IR theory, Kenichiro Hirano made an even more explicit attempt to construct a cultural methodology for the theorisation of IR. Born in 1937, Hirano is also a scholar in the Japanese diplomatic history tradition. He received undergraduate and master's degrees in the liberal arts from Tokyo University and obtained his Ph.D from Harvard. He returned to Tokyo University after his doctorate and taught IR and intercultural relations there before moving to Waseda University in Tokyo. He has published wide-ranging works on IR and cultural interactions in world affairs and he has been consistent in his methodology in the sense that he has specifically focused on culture in theorising world affairs.

If one is to study IR in relation to culture in Japan, Hirano's textbook Kokusai Bunkaron [International Cultural Theory] is usually referred to as the starting point of the subject, ${ }^{38}$ and is now regarded as essential for students of cultural IR. Like Iriye, Hirano has also been concerned mainly with the term 'culture' and diplomatic history. However, his approach is substantially different from Iriye's. Iriye defines culture as a separate realm of inquiry, and thus culture appears to be an object of inquiry. By contrast, Hirano contends that culture is the methodology of inquiry not an object, and thus a way of seeing world affairs. In other words, whereas Iriye's method is to look at culture, Hirano attempts to analyse world affairs as a whole using an anthropological and cultural methodology, looking at the world through cultural lenses.

Hirano argues that we should not only focus on culture but also identify the cultural influence on the theorisation process of IR. According to Hirano, theorisation is also a human activity and thus inevitably cultural; consequently, he says, 'IR itself is cultural'. ${ }^{39}$ Hirano maintains that in order to inquire into world affairs culturally, we must focus upon peripheries. He defines culture as 'distinctive "bodies" of a variety of individuals and groups' that can be regarded as subjects performing important roles in shaping the world. ${ }^{40}$ In the age of globalisation, these subjects are no longer static. Instead, they are active and dynamic in terms of geography and social class. People are mobile, transcending national borders and socio-political boundaries with ease, and continuously transforming themselves through their interactions with others. This is precisely why Hirano deliberately focuses on the margins and peripheries; because the subjectivities transforming themselves into something else are to be found where different cultures encounter each other. This encounter always resides at the margins, not at the core, of each culture. Thus, the prevailing mainstream IRT should be severely criticised for its lack of attention to the ever-changing nature of identities, which often starts on the margins.

A typical example of Hirano's argument on international cultural relations is his stern critique of Samuel Huntington's 'clash of civilisations' thesis. Hirano contends that Huntington's theory confuses two similar but different words: civilisation and culture. Huntington unquestionably uses these two words in an interchangeable manner, and thus he confuses a clash of civilisations with cultural friction. Hirano strictly distinguishes between these two words and argues that cultural friction leads to efforts by the parties involved for reconciliation, thus becoming one of the main means of avoiding a clash of civilisations.

\footnotetext{
${ }^{38}$ Kenichiro Hirano, Kokusai Bunkaron [International cultural relations] (Tokyo: Tokyo University Press, 2000).

39 Hirano, Kokusai Bunkaron, ii.

40 Hirano, Kokusai Bunkaron, ii.
} 
Hirano maintains that this moment takes place mainly in individuals' minds. Citing cases of Japanese citizens and politicians encountering the West in the 19th century as examples, Hirano argues that it is the hope of reconciliation, which resides in people's minds, that makes it possible to eventually avoid a clash of civilisations. In this manner, cultural frictions are, Hirano argues, always reconciled locally. However, the possibility of local reconciliations of cultural friction has been intentionally eliminated from Huntington's argument in order to emphasise the confrontational nature of international civilizational relations. ${ }^{41}$ Thus, to Hirano, Huntington's exclusive focus on a clash of civilisations rather than cultural friction is a characteristic of his theorisation on the basis of a perception of sovereign actors that is very much a Western cultural product, and the concept of a clash is pre-given and assumed prior to civilisation in the theorisation process of the post-Cold War political environment.

The concept of 'cultural friction' deserves a more detailed discussion here. According to Hirano, cultural friction is destined to be reconciled. As is discussed elsewhere, Huntington's civilisation is described in an essentialist manner, while Hirano's is more constructivist, because the reconciliation process affects the process of identity construction for the parties involved. Cultural frictions open a space for dialogue between the conflicting parties and transform their identities. It is important, again, that the transformation of identities is particularly salient on the peripheries, rather than at the core of each culture. Therefore, Hirano's focus is naturally placed on those 'bodies' at the margins of cultures.

In this way, Hirano's argument about international cultural relations provides new lenses through which we can look at world affairs. By using Hirano's methodology, we can focus on cultural relations not only among different nations but also among different individuals and communities. However, his approach has failed to capture the attention of an IR audience and has not been recognised as a legitimate approach to world affairs in the Japanese IR community; he has thus set up a new academic society to put forth his views, the Japan Society of Intercultural Studies (JSIC), of which he holds the post of founding chair.

\section{The Study of Regional History}

Despite unceasing academic efforts with regard to culture and IR and the significant addition of a new dimension to traditional IR made by Iriye and Hirano, mainstream IR theorists still regard IR as an academic discipline constructed on the basis of an ahistorical perception of security and state sovereignty. Those working on the relationship between culture and IR have found a place within a different academic subject, namely, the study of regional history. The most notable scholar in this context is Takeshi Hamashita, a historian and regional studies scholar focusing on Asia.

Hamashita was born in Shizuoka Prefecture and studied at the University of Tokyo. He has written on a wide variety of subjects, such as modern Chinese history, the tribute system, Okinawa and Japanese imperialism and critical IR. Of these, his interpretation of the Chinacentred world system until the 18th century and its subsequent demise is widely known; indeed, his argument inspired Andre Gunder Frank's Re-Orient ${ }^{42}$ and challenges John King Fairbank's interpretation of the tribute system as the cause of China's failure to protect itself from Western dominance. ${ }^{43}$

41 Hirano, Kokusai Bunkaron, 28-33.

42 Andre Gunder Frank, Re-Orient: Global Economy in the Asian Age (Berkeley: University of California Press, 1998).

43 John King Fairbank and Ta-tuan Ch'en, eds., The Chinese World Order: Traditional China's Foreign Relations (Cambridge: 
The tribute system has been the central focus of the so-called recently emerging Chinese School, which includes David Kang and Qin Yanqing. ${ }^{44}$ The scholars show how stable the world was under the tribute system; according to Kang, East Asia enjoyed peace and order from the $14^{\text {th }}$ to the 19th century until the violent arrival of Western imperialism. In contrast to the Westphalian system of interstate relations, which is defined by its formal equality and incessant interstate conflict, the East Asian tribute system was characterised by formal inequality and 'centuries of stability among the core participants' ${ }^{45}$

Kang's and Qin's arguments were developed relatively recently, but Hamashita had established his argument concerning governance and the tribute system as early as the 1980s. It is also worth noting here that Hamashita's analysis is in some ways far more radical; he is, like Hirano, more concerned with those on the margins than in the core. Consequently, his analysis is periphery-focused and rarely uses China or Japan as the reference point.

According to Hamashita, the world before 1800 was China-centred. The development of China in that era was indeed supported by the tribute system, which involved such tributary states as Japan, Korea, Taiwan, Ryukyu, Vietnam and the Philippines. These countries sent tributary missions to China regularly, while China sent envoys to tributary states for official recognition when they had new rulers. The merchants and traders who accompanied the envoys are important in this context. Hamashita notes that the volume of private trade increased over time, and the categories and quantities of goods traded were officially regulated. As a consequence, the main purpose of the tribute trade 'came to be the pursuit of profits through the unofficial trade that was ancillary to the official system' ${ }^{46}$

On the basis of his account of the tribute system, Hamashita develops his contention that the core of the world economy resided in East Asia up until 1800, and Europe was no exception.

George III's envoy Lord Macartney was dispatched to the court of the Ch'ien Lung Emperor with the title of Ambassador and Plenipotentiary Extraordinary in 1793. Macartney recorded in his journal, 'I pretend not to notice that "English Ambassador with Tribute to the Chinese Emperor" is written on the ship's flag, and I have not yet complained about it. Given an appropriate opportunity, I shall give them warning, ${ }^{47}$

According to Hamashita, China lost its momentum around 1800 in terms of its transcendental power over its tribute states; the above passage was written around that time, and still shows China's perception of its world, clearly regarding England as a tribute state.

Hamashita contends that the study of regional history has the tremendous potential to change the widespread perception of IR about the world. It shows the possibility of different interpretations of world history, as the history of the tribute system shows us. It also proves that the world order has been constructed not on the basis of a universalised principle of non-intervention or state sovereignty. It is, rather, constructed on the basis of interactions of economy and culture, at the centre of which human beings, not nation-states, reside, regardless of their physical locations. While it is still possible to argue that the tribute system

Harvard University Press, 1968)

44 David C. Kang, East Asia Before the West: Five Centuries of Trade and Tribute (New York: Columbia University Press, 2010), Qin Yaqing, "International Society as a Process: Institutions, Identities, and China's Peaceful Rise," The Chinese Journal of International Politics 3, no. 2 (2010): 129-53.

45 Kang East Asia, 201.

46 Takeshi Hamashita, "Tribute and Emigration: Japan and the Chinese Administration of Foreign Affairs," Senri Ethnological Studies 25 (1989): 69-86; Giovanni Arrighi, "States, Markets, and Capitalism, East and West," Positions 15, no. 2 (2007): 261.

47 Hamashita, "Tribute and Emigration," 76-7. 
itself was hierarchical, and thus, a first glance, constructed upon a universalised principle of power politics, it was, in reality, flexible and fluid in terms of economic and cultural exchanges among peoples, and took place across blurred state borders. ${ }^{48}$

Hamashita's account of regional history also shows us the importance of looking through the lenses of the periphery. In this context, Hamashita was particularly concerned with the history of Ryukyu. Between the 17th and 19th centuries, Ryukyu was under the control of two different states at the same time, China and Japan. However, these suzerain states did not interfere with each other, and practically ignored the fact that Ryukyu was at least formally under the control of the other state. What is remarkable here is that the system of blurred state boundaries made it possible in practice for a state to come under the control of two different jurisdictions. In other words, the Ryukyu Kingdom exploited the system of blurred boundaries to maintain its relative independence from both big powers. In this way, the study of regional history shows a different interpretation of state sovereignty and the construction of state identities, and proves that the autonomous state sovereignty of non-interventionism is merely a particular, provincial interpretation.

Thus far, Hamashita's argument against mainstream IR has been the most advanced form of IR theorisation residing, or at least regarded by most IR scholars as residing, outside the IR community of Japan.

\section{Conclusions: Some Implications for Post-Western IRT}

What, then, can we learn from the genealogy of the Japanese IR of culture? Inoguchi, as I mentioned earlier, emphasises the differences in the four traditions of Japanese IR: the Staatslehre tradition, Marxism, Historicism and American-style methodology. Each of these has its own characteristics and disadvantages, according to Inoguchi, and he emphasises the differences among them. However, researchers from other countries in the Asia-Pacific focus on their similarities. Ching-Chang Chen, for instance, argues that while these four traditions seem to be at first glance based on different assumptions and theoretical compositions, none of them pays sufficient attention to the narratives developed in other countries of Asia as 'Japanese IR academics believe they can learn little from the concepts and experiences of other Asian countries, because Asia lacks Westphalia'. ${ }^{49}$ In fact, all four traditions Inoguchi discusses have their origins in the European or American tradition and were imported to Japan over the course of its modernisation. Therefore, it can be argued that the answer to why the study of regional history has long been neglected in Japanese IR literature lies in the history of IR as an academic discipline itself, which developed as a subject to make sense of and analyse the events and occurrences taking place in the world. The world Westernbased IR sees is divided by strict and robust state boundaries, and thus studies focusing on different interpretations and explanations of the world based on a regional history remain outside Japanese IR to the extent that the latter is a self-claimed discipline within the Western tradition and based on Westphalian subjectivity.

This situation is precisely what culturalists argue against. For them, history must be narrated from the margins if our intellectual activities are to understand the world more in terms of concrete or 'bodily' human interactions than of abstract concepts of nation-states.

${ }^{48}$ Takeshi Hamashita, China, East Asia, and the Global Economy: Regional and Historical Perspectives (New York: Routledge, 2008).

49 Chen, "The Im/Possibility of Building Indigenous Theories," 471 
Narrating the history of the margins has at least two important and intertwined meanings. First, it gives us a clue to aspects of world affairs that have never been revealed, complementing and reinforcing a more precise understanding of the contemporary world and thus becoming the basis of our future vision. Second, while it complements the existing knowledge of contemporary IR, it also relativises the traditional knowledge of IR. This relativisation is in some ways political; because the world has been constructed upon a particular perception, it has benefited those who share the same view and has excluded those who do not. Thus, narrating the world from the margins has the ethical result of 'provincialising' the mainstream narrative, and thus its action is political.

What does this mean specifically for post-Western IR discourse? There are at least three implications:. First, Hirano's and Hamashita's analyses reveal how much our perception is biased by the Westphalian presumptions of state sovereignty and strict state borders, as well as the extent to which we look at the world on the basis of strictly demarcated borders. Hirano argues that we tend to focus more on the core units of analysis, not on the peripheries. When we make inquiries into Japanese foreign policy, for instance, this mainly denotes Tokyo's political decisions about external relations, not Okinawa's calls to be rid of U.S. bases. Hamashita's investigation of the tribute system also shows that the stable political order in existence before the arrival of European modernity was mainly supported by the enormous amount of transactions and exchanges in economic and cultural relations across boundaries, which was, in turn, guaranteed and encouraged by a system of blurred borders between the concerned states.

Second, however, there is a strong and robust obstacle to such unconventional arguments as Hirano's and Hamashita's. It is clear that their arguments contribute to the existing IR literature by providing an opportunity to reflect upon our mind-set in terms of state sovereignty and strict boundaries. However, the genealogy of Japanese IR, in which mainstream scholars have ignored the argument about the importance of culturalist methodology, make it clear that a different interpretation and understanding from the mainstream Westphalian perception towards world affairs has difficulty in being sufficiently recognised.

Third, we need to keep in mind that perceptions based on such language as the Westphalian nation-state and geographical division, for example, West and East, is more persistent than we can imagine. This situation is precisely why colonial studies specialists of Japan were drawn into the discourse of anti-Western regionalism of the Great East Asian Co-prosperity Area before World War II. In fact, there is an irresistible temptation in every moment we talk about world affairs to use such concepts as Japan, China and the U.S. as nationstates in the Westphalian sense, or of West and East in terms of civilisation and modernity. This temptation appears in a variety of forms. As the case of culturalist methodology in Japan indicates, we may simply be excluded from the discipline of IR unless we use the language of the nation-state or geographical division. Alternatively, in order to obtain the recognition of the IR community, we may be forced to make a deal by using the concept of nation-states to formulate our theory, as the Kyoto School philosophers did before World War II. ${ }^{50}$ However, as a consequence, we may find ourselves thinking of the contemporary world and the decline of U.S. hegemony in terms of strictly demarcated state boundaries or a dichotomised confrontation of West and East, and thus wondering uncritically which 
nation-state or geographical area will be the next hegemon. This seems particularly salient in light of the recent overwhelming popularity of the 'China Rising' discourse. However, as Hamashita suggests, what we need to examine in making sense of contemporary world affairs is not which nation-state in the Westphalian sense will become the next provider of universalised political principles, but how we stop using our exclusivist language, based on the Westphalian system, in a post-Western world.

\section{Bibliography}

Acharya, Amitav. "International Relations Theory and the 'Rise of Asia'." In Oxford Handbook of the International Relations of Asia, edited by Saadia Pekkanen, John Ravenhill, and Rosemary Foot, 120-40. New York: Oxford University Press, 2015.

Arrighi, Giovanni . "States, Markets, and Capitalism, East and West.” Positions 15, no. 2 (2007): 251-84.

Carr , E. H. The Twenty Years' Crisis: 1919-1939. London: Macmillan, 1946.

Chen, Ching-Chang. "The Absence of Non-Western IR Theory in Asia Reconsidered." International Relations of the Asia-Pacific 11, no. 1(2011): 1-23.

"The Im/Possibility of Building Indigenous Theories in a Hegemonic Discipline: The Case of Japanese International Relations." Asian Perspective 36, no. 3 (2012): 463-92.

Chen, Kuan-Hsing. “Takeuchi Yoshimi’s 1960 'Asia as Method' Lecture.” Inter-Asia Cultural Studies 13, no. 2 (2012): 317-24.

Cox, Robert. "Social Forces, States and World Orders: Beyond international relations theory." Millennium 10, no. 2 (1981): 126-55.

Fairbank, John King, and Ta-tuan Ch'en, eds. The Chinese World Order: Traditional China's Foreign Relations. Cambridge: Harvard University Press, 1968.

Frank, Andre Gunder. Re-Orient: Global Economy in the Asian Age. Berkeley: University of California Press, 1998. Goto-Jones, Chris. Political Philosophy in Japan: Nishida, the Kyoto School, and Co-Prosperity. London: Routledge, 2005.

—, ed. Re-Politicising the Kyoto School as Philosophy. London: Routledge, 2008

Hamashita, Takeshi. China, East Asia, and the Global Economy: Regional and Historical Perspectives. New York: Routledge, 2008.

. "Tribute and Emigration: Japan and the Chinese Administration of Foreign Affairs." Senri Ethnological Studies 25 (1989): 69-86

Hirano, Kenichiro. Kokusai Bunkaron [International cultural relations]. Tokyo: Tokyo University Press, 2000. Hoffmann, Stanley. “An American Social Science: International Relations.” Daedalus 106, no. 3 (1977): 41-60. Hook, Glenn D., Julie Gilson, Christopher W. Hughes, and Hugo Dobson. Japan's International Relations: Politics, Economics and Security. London: Routledge, 2001.

Hook, Glenn D., and Richard Siddle, eds. Japan and Okinawa: Structure and Subjectivity. London: Routledge Curzon, 2001.

Hotta, Eri. Japan 1941: Countdown to Infamy. New York: Alfred A. Knopf, 2013. . Pan-Asianism and Japan's War: 1931-1945. Basingstoke: Palgrave/Macmillan, 2007.

Inoguchi, Takashi. “Are There Any Theories of International Relations in Japan?" International Relations of the Asia-Pacific 7, no. 3 (2007): 369-90.

Inoguchi, Takashi, and Paul Bacon. "The Study of International Relations in Japan: Towards a More International Discipline.” International Relations of the Asia-Pacific 1, no. 1 (2001): 1-20.

Iriye, Akira. Cultural Internationalism and World Order. Baltimore: Johns Hopkins University Press, 1997.

—. Shin Nihon no Gaiko: Chikyuka Jidai no Nihon no Sentaku [New diplomacy of Japan: Japan's choice in the global era]. Tokyo: Chuokoron, 1991. 
Kang, David. East Asia before the West: Five Centuries of Trade and Tribute. New York: Columbia University Press, 2010.

Kawata, Tadashi, and Saburo Ninomiya. "The Development of the Study of International Relations in Japan." The Developing Economies 2, no. 2 (1964): 190-204.

Keene, Edward. Beyond Anarchical Society: Grotius, Colonialism and Order in World Politics. Cambridge: Cambridge University Press, 2002.

Lee, Seok-Won. "Empire and Social Science: Shinmei Masamichi and the East Asian Community in Interwar Japan.” Social Science Japan Journal 17, no. 1 (2013): 59-76.

Murata, Koji . "The Evolution of Japanese Studies of International Relations." Japanese Journal of Political Science 11, no. 3 (2010): 355-65.

Nakano, Ryoko. “'Pre-History’ of International Relations in Japan: Yanaihara Tadao's Dual Perspective of Empire.” Millennium 35, no. 2 (2007): 301-20.

Yaqing, Qin. "International Society as a Process: Institutions, Identities, and China's Peaceful Rise." The Chinese Journal of International Politics 3, no. 2 (2010): 129-53.

“A Relational Theory of World Politics." International Studies Review 18, no. 1 (2016): 33-47.

"Rule, Rules, and Relations: Towards a Synthetic Approach to Governance." The Chinese Journal of International Politics 4, no. 2 (2011): 117-45.

Sakai, Tetsuya. Kindai Nihon no Kokusai Chitsujo [International order of modern Japan]. Tokyo: Iwanami, 2007.

Shani, Giorgio. "Towards a Post-Western IR: The Umma, Khalsa Panth, and critical international relations theory." International Studies Review 10, no. 4 (2008): 722-34.

Shimizu, Kosuke. “The Ambivalent Relationship of Japan's Soft Power Diplomacy and Princess Mononoke: Tosaka Jun's philosophy of culture as moral reflection.” Japanese Journal of Political Science 15, no. 4 (2014): 683-98.

- "Materializing the 'Non-Western': Two Stories of Japanese Philosophers on Culture and Politics in the Inter-war Period." Cambridge Review of International Affairs 28, no. 1 (2015): 3-20.

_. "Nishida Kitaro and Japan's Interwar Foreign Policy: War Involvement and Culturalist Political Discourse." International Relations of the Asia-Pacific 11, no. 1 (2011): 157-83.

Smith, Steve, Ken Booth, and Marysia Zalewski. International Theory: Positivism and beyond. Cambridge: Cambridge University Press, 1998.

Suzuki, Shogo. Civilization and Empire: China and Japan's Encounter with European International Society. London: Routledge, 2009.

Tansman, Alan, ed. The Culture of Japanese Fascism. Durham, N.C.: Duke University Press, 2009.

Yamamoto, Kazuya. "International Relations Studies and Theories in Japan: A Trajectory Shaped by War, Pacifism, and Globalization." International Relations of the Asia-Pacific 11, no. 2 (2011): 259-78.

Young, Louise. Japan's Total Empire: Manchuria and the Culture of Wartime Imperialism. Berkeley: University of California Press, 1998.

Zhao, Tingyang. "Rethinking Empire from a Chinese Concept 'All-under-Heaven'." Social Identities 12, no. 1 (2006): 29-41. 